\title{
Disturbing corporate personality to remedy a fraudulent incorporation: an analysis of the piercing principle
}

\author{
STEPHEN GRIFFIN
}

Emeritus Professor of Corporate Law, University of Wolverhampton

\begin{abstract}
$\underline{\text { Abstract }}$
Following two recent decisions of the Supreme Court it has been confirmed that the ability to disturb corporate personality by piercing the corporate veil is as an established principle but one that should be used only as a tool of last resort. In practice the deployment of this 'piercing principle' will be a rarity to the point of near extinction. This paper will contend, however, that the Supreme Court's endorsement of a limited piercing principle does not address fully the commercial necessity of disturbing the corporate personality of companies incorporated to pursue a fraudulent activity; further, that this lacuna could have been averted had the Supreme Court identified a related but broader 'piercing concept' which is established impliedly in the case law.
\end{abstract}

\section{Introduction}

A fundamental principle of corporate law, established as the Salomon principle, ${ }^{1}$ provides A that from the date of a company's incorporation, the company is to be regarded as a distinct legal entity; a 'body corporate', possessing legal rights and responsibilities in a manner akin to a natural person. ${ }^{2}$ The independent legal status of the corporate entity is said to cast a 'veil' between the company and its members, to the extent that any liability attached to a limited company by way of share capital ${ }^{3}$ will fall ordinarily on the body corporate and not on the company's members. ${ }^{4}$

At common law, but in exceptional circumstances, it may be possible to pierce the protective veil of incorporation to expose the company's controller (ordinarily the controlling shareholder) to a liability or responsibility that would otherwise have fallen exclusively on the corporate entity. The liability of the company's controller may be a joint

1 The principle is derived from the decision of the House of Lords in Salomon v A Salomon \& Co Ltd [1897] AC 22.

2 Incorporated into the companies legislation as Companies Act (CA) 2006, s 16.

3 A member of a company with fully paid-up shares will cease to incur any liability to contribute to the debts of the company, see CA 2006, s 3(2).

4 Alternatively, a limited liability company may be incorporated by guarantee, see CA 2006, s 3(3). In such a case and following the company's winding-up, a member's liability will be determined by the sum of the guarantee. 
liability with the company or, in some instances, the corporate veil may be ignored in its entirety to impose an absolute liability against the controller. ${ }^{5}$

The exact scope of the 'piercing doctrine' is, however, confused and to a significant extent. ${ }^{6}$ The purpose of this paper is to ultimately explore, analyse and comment on this confusion to a conclusion that in one instance 'veil piercing' may properly be regarded as an established principle. This established principle arises in a situation where a company was incorporated to the objective of evading a pre-existing legal obligation of its controller (hereafter referred to in this paper as the 'evasion principle'). ${ }^{7}$ This paper will contend that this established piercing concept is, however, but a constituent part of a wider piercing concept (hereafter referred to in this paper as the 'fraudulent incorporation concept') which, it is asserted, is rooted in the Salomon judgment. ${ }^{8}$ In this respect and as a matter of methodology, the paper will analyse the development, deployment and current status of the piercing doctrine, a journey which will culminate in two recent decisions of the Supreme Court. ${ }^{9}$ As a starting point for this journey, it is imperative to consider first the judgment of the House of Lords in Salomon v A Salomon \& Co Ltd. ${ }^{10}$

\section{THE SALOMON PRINCIPLE}

In Salomon $v$ A Salomon \& Co Ltd, the fundamental issue before the House of Lords was whether a company, dominated and controlled by one person (a company commonly referred to as a 'one-man-type company') was legally incorporated in accordance with the terms of the then governing companies legislation, namely the Companies Act $1862 .{ }^{11}$ If, in accordance with the terms of the Act, the company was incorporated legitimately, the responsibility for discharging corporate debts and liabilities rested solely with the company in its guise as a distinct legal entity. ${ }^{12}$ Section 6 of the Companies Act 1862, specified that a company had to be incorporated for a lawful purpose and that as a minimum requirement should have seven members. A Salomon \& Co Ltd complied with

5 The court will ordinarily impose an absolute liability or responsibility on the person who controls the company in circumstances where the company is devoid of any assets.

6 There are numerous academic articles in which these contentious issues have been considered, see generally e.g. S Ottolengui, 'From Peeping behind the Corporate Veil to Ignoring It Completely' (1990)53 MLR 338; J H Farrar, 'Fraud, Fairness and Piercing the Corporate Veil' (1990) 16 Canadian Business Law Journal 474; C Mitchell 'Lifting the Corporate Veil in the English Courts: An Empirical Study' (1999) 3 Company Financial and Insolvency Law Review 15; D Michael 'To Know a Veil' (2000) 26 Journal of Corporation Law 41; M Moore 'A Temple Built on Faulty Foundations: Piercing the Corporate Veil and the Legacy of Salomon $v$. Salomon' (2006) Journal of Business Law 478; C H Tham, 'Piercing the Corporate Veil: Searching for an Appropriate Choice of Law Rules’ [2007] Lloyd's Maritime and Commercial Law Quarterly 22.

7 The term 'evasion principle' was first used by Lord Sumption in Prest v Petrodel Resources Ltd [2013] UKSC 34; [2013] 2 AC 415.

8 The vast majority of legal systems recognise that a company's distinct legal status may be subject to exceptions. In civil law jurisdictions, the juridical basis of the exceptions is generally the concept of an abuse of rights, see e.g. the decision of the International Court of Justice in Barcelona Traction, Light and Power Co Ltd (Belgium v Spain) (Second Phase) [1970] ICJ Rep 3. Here, a limited principle was advanced to permit the piercing of the corporate veil in cases of misuse, fraud, malfeasance or evasion of legal obligations.

$9 \quad$ VTB Capital plc v Nutritek. [2013] UKSC 5; [2013] 2 AC 337 and Prest (n 7).

10 Salomon (n 1).

11 CA 1862, s 6.

12 For case examples relating to the acceptance of the incorporation of a 'one-dominated business' pre-Salomon, see e.g. Re George Newman \& Co [1895] 1 Ch 674 and Farrar v Farrar (1889) 40 Ch D 395. 
the latter requirement, ${ }^{13}$ having also appeared, prima facie, to have complied with the former requirement. ${ }^{14}$

Within a year of its incorporation, A Salomon \& Co Ltd fell into an insolvent state, a dire position from which it would not escape. ${ }^{15}$ Following the company's subsequent liquidation, the realisation of its assets was insufficient to satisfy the totality of its unsecured debts. The company's liquidator sought to hold the company's controlling shareholder, Mr Salomon, personally liable for the debts, arguing that the company's incorporation fell outside the true spirit and intent of the Companies Act 1862. In the ensuing litigation in both the High Court ${ }^{16}$ and the Court of Appeal, ${ }^{17}$ it was accepted that the company was a distinct legal entity; the company having been formally registered in compliance with the 1862 Act. Nevertheless, both the High Court and Court of Appeal considered that A Salomon \& Co Ltd had not met the intent of the 1862 Act's requirement that a company should be incorporated by seven persons 'associated for a lawful purpose'. The lower courts interpreted this requirement to mean that all seven persons who became members of the company should have a bona fide intention of participating in the trading venture. Although, prior to its incorporation Mr Salomon's business had been profitable, in effect, the lower courts viewed its transformation into a limited liability company and its perilous and rapid decline to be no more than a scandalous device to defraud creditors. ${ }^{18}$ To this end the lower courts disturbed the corporate status of A Salomon \& Co Ltd to make Mr Salomon personally liable for the company's debts.

In the High Court, Vaughan Williams J concluded that the relationship between $\mathrm{Mr}$ Salomon and the company was one of agency, Mr Salomon having exerted absolute control over the company. As the principal in the agency relationship, Mr Salomon was held to be personally liable to repay the unsecured debts. ${ }^{19}$ In the matter of Salomon's personal liability, the Court of Appeal concurred with the decision of the High Court, although declaring that the legal relationship between Mr Salomon and the company was

13 The company acquired Mr Salomon’s business at a price of approximately $£ 39,000$. In consideration for its acquisition of the business the company issued 20,006 $f 1$ shares, of which 20,000 were allotted to Mr Salomon, with one share each allotted to his wife and five children. In addition, Mr Salomon was issued with debentures (secured against the assets of the company by way of a floating charge) to the value of $f_{10}, 000$. Mr Salomon took the remainder of the sale price in cash.

14 The business was owned previously by Mr Salomon and was incorporated to continue a pre-existing and successful business enterprise. The incorporated company was purportedly to operate as a family business, but under the dominant control of Mr Salomon. In effect, the six other shareholders were to play no significant role in the running and organisation of the business affairs of the company.

15 The company's failure resulted from unforeseen circumstances falling outside the contemplation of Mr Salomon, namely a depression in the market coupled with adverse trade union activity in the industry; both factors caused significant disruption to the company's business operations.

16 Broderip v Salomon [1895] 2 Ch 323.

17 Ibid.

18 In the Court of Appeal, Lopes LJ remarked: 'If we were to permit it to succeed, we should be authorising a perversion of the Joint Stock Companies Act. We should give vitality to that which is a myth and a fiction... To legalise such a transaction would be a scandal.' (n 16) 341.

19 An agency relationship recognises the existence of two distinct legal entities (the principal and the agent). The principal is responsible and liable for the acts of its agent. Agency may be tentatively defined as a relationship which is based upon the express or implied consent of both the agent and the principal, whereby the agent is made subject to the principal's absolute control and will, to the extent that the agent conducts its business affairs without independence and does so to the ultimate benefit of its principal (see e.g. Garnac Grain Co Inc v HMF Faure and Fairclough Ltd [1968] AC 1130,1137). 
not one of agency but rather one governed by the law of trusts. ${ }^{20}$ Accordingly, Mr Salomon was liable as the beneficiary in the trust relationship.

On appeal to the House of Lords, the House unanimously refuted the assertions of the lower courts. The House recognised that the High Court's finding of an agency relationship in a one-man-type company would be to defeat the very objective of incorporating this type of company. There could be no agency relationship. As Lord Herschell explained:

In a popular sense, a company may in every case be said to carry on business for and on behalf of its shareholders; but this certainly does not in point of law constitute the relation of principal and agent between them or render the shareholders liable to indemnify the company against the debts which it incurs. ${ }^{21}$

In relation to the Court of Appeal's assertion that there had been a trust relationship, Lord Davey remarked:

There was certainly no express trust for the appellant; and an implied or constructive trust can only be raised by virtue of some equity. I took the liberty of asking the learned counsel what the equity was, but got no answer. ${ }^{22}$

Applying a literal interpretation of the 1862 Act, the House held that a company could be incorporated providing it had at least seven members, irrespective of whether or not all seven members made a noteworthy financial and/or working contribution to the company. As the incorporation of A Salomon \& Co Ltd complied fully with the registration procedures and intent of the 1862 Act, the company was a legitimate entity and therefore responsible for the repayment of its own debts. ${ }^{23}$ Nevertheless, implicit from the obiter comments of their Lordships was the inference that, had the company been incorporated to pursue an illegitimate purpose, namely of a fraudulent, dishonest or mythical design, then the otherwise legitimate incorporation of the company could be disturbed. ${ }^{24}$ For example, Lord Halsbury observed :

If there was no fraud and no agency, and if the company was a real one and not a fiction or a myth, every one of the grounds upon which it is sought to support the judgment is disposed of . . .25

Commenting on the judgment of the Court of Appeal, Lord Macnaughten stated:

If, however, the declaration of the Court of Appeal means that Mr. Salomon acted fraudulently or dishonestly, I must say I can find nothing in the evidence to support such an imputation. ${ }^{26}$

With the benefit of hindsight, it was most unfortunate that neither Lord Halsbury or Lord Macnaughten sought to explain the type and nature of the impropriety that would justify a finding of an illegitimate incorporation. For example, in establishing a fraud, was it necessary to establish that a controlling shareholder subjectively or objectively intended to exploit the incorporation process to deceive an innocent third party? Or, alternatively, could the term fraud be equated with an equitable fraud, objectively identifiable by the unconscionable behaviour of the individual who controlled the company? As, however,

20 It is unclear, however, what type of trust the Court of Appeal had in mind.

21 Salomon (n 1) 43.

22 Ibid 56.

23 Ibid, see e.g. the judgment of Lord Macnaughten, 46.

24 See, C M Schmitthoff, 'Salomon in the Shadow' (1976) Journal of Business Law 305.

25 Salomon (n 1) 33.

26 Ibid 52. 
the Salomon case provided no real evidence of a $\mathrm{fraud}^{27}$ or illegitimate purpose, ${ }^{28}$ such questions were extraneous to its outcome. ${ }^{29}$ Accordingly, the precise subjective or objectively perceived motive for incorporation ${ }^{30}$ became irrelevant. ${ }^{31}$

Of the six members of the House who heard the case, only Lord Davey sought to allude to the consequences which, in his Lordship's opinion, should be attached to an illegitimate incorporation. Lord Davey's suggested remedy was not that an illegitimate incorporation should result in a disturbance of the company's corporate veil but rather that the company's incorporation and existence should be nullified. ${ }^{32}$ Other than in one specific instance, ${ }^{33}$ Lord Davey's suggestion was never adopted, which is understandable given that the consequences of treating a company as a nullity would be that any of its outstanding contractual obligations would be deemed void. ${ }^{34}$

\section{Piercing the corporate veil: the justice argument}

In case law subsequent to Salomon, it is feasible to suggest that by applying a flexible, but nonetheless viable, interpretation of the obiter comments of both Lord Macnaughten and Lord Halsbury (previously alluded to above), a strict alignment to the Salomon principle could be disturbed in circumstances where a company was incorporated to pursue an unjust business activity of a type analogous to an equitable fraud. An equitable fraud would be expected ordinarily to embrace a wide range of misconduct to include instances of unfair conduct, undue influence, abuse of confidence and unconscionable bargains. ${ }^{35}$

27 It was alleged that Mr Salomon committed a fraud by overvaluing his business and because the company did not have a properly constituted board of directors. The House of Lords concluded that the substance of these allegations did not amount to fraud, see e.g. the comments of Lord Davey in Salomon (n 1) 57.

28 A further blemish on Mr Salomon's potential credibility was that, at the time of the company's incorporation, he was issued with a $£ 10,000$ debenture. The debenture was secured against the company's assets giving him a repayment priority on the company's insolvency. The debenture transaction was, however, legally registered and therefore afforded notice of its existence to the company's other creditors. The fact that the debenture was subsequently sold to a Mr Broderip (for only $\mathcal{f}^{5} 5000$ ) and the sale funds ploughed back into the company provided cogent evidence that Mr Salomon's desire was to rescue, as opposed to exploit, the company's fortunes.

29 As Lord Halsbury observed, Mr Salomon was 'not shown to have done or to have intended to do anything dishonest or untrustworthy, but to have suffered a great misfortune without any fault of his own ...' (n 1) 34.

30 In Salomon, the motive for incorporation was probably to create a formal family business with the added benefit of a limited liability status.

31 See the comments of Lord Halsbury: Salomon (n 1) 30.

32 Ibid 56-57.

33 The Crown is given a limited power to declare that a company is a nullity in circumstances where the company was formed for an unlawful purpose, see $\mathrm{R} v$ Registrar of Companies [1991] BCLC 476.

34 If a company is deemed to be a nullity it logically follows that it could never have legitimately entered the process of being formed (incorporated) and therefore its controller could never be made personally liable on an alleged pre-incorporation contract. Pre-incorporation contracts are governed by CA 2006, s 51. The provision is interpreted strictly, See e.g. Oshkosh B'Gosh Inc v Dan Marbel Ltd [1989] BCLC 507.

35 See e.g. the comments of Lord Selborne LC in Earl of Aylesford v Morris (1873) LR 8 Ch App 484, 490-91, and those of Viscount Haldane LC in Nocton v Lord Ashburton [1914] AC 932. More recently, see the comments of Patten LJ in De Bruyne v De Bruyne [2010] EWCA Civ 519, para 51. 
A justice criterion for piercing the corporate veil was accepted by Lord Denning in both Littlewoods Mail Order Stores Ltd v IRC ${ }^{36}$ and Wallensteiner v Moir, ${ }^{37}$ and by Cumming Bruce LJ, in Re a Company. ${ }^{38}$ Yet, by its very nature the ambit of a justice criterion lacked precision, flawed by the potential uncertainty and inconsistency that would inevitably be attached to its universal application. ${ }^{39}$ While any decision to pierce the corporate veil would be touched naturally by the justice of the particular case, as a precise piercing principle, the justice criterion was far too vague and imprecise. ${ }^{40}$ In matters governing the sanctity of the corporate veil, the commercial world required a more rigid adherence to the Salomon principle and greater certainty and clarity in relation to when that principle could be disturbed.

The judicial condemnation of the use of a justice criterion was implicit in the decision of the House of Lords in Woolfson $v$ Strathclyde Regional Council, ${ }^{41}$ a condemnation emphasised by the subsequent judgment of the Court of Appeal in Adams v Cape Industries. ${ }^{42}$ Following Adams, an ability to pierce the corporate veil was made subject to precise and strict guidelines. The guidelines provided that the corporate veil should only be pierced in a situation where 'special circumstances exist indicating that the company is a mere façade concealing the true facts'. ${ }^{43}$ In Adams, the Court of Appeal provided two scenarios in which a façade could be established, namely, where a company was deemed to be the agent of its controlling shareholder ${ }^{44}$ or, alternatively, in a situation (now referred to as the 'evasion principle') where the individual who controlled the company sought to evade a pre-existing legal obligation by hiding it behind the protective 'corporate shield' of a registered company. ${ }^{45}$ In relation to the agency category and following on from the reasoning in Salomon, it is probable that the Court of Appeal considered that the agency form of façade should only be made applicable in cases involving a group of companies. ${ }^{46}$

In addition to curtailing a justice criterion in the context of veil-piercing, the decision in Adams also refuted the practice of piercing the corporate veil on the ground that a group of companies constituted a single 'economic entity'. Prior to Adams, it had been

36 [1969] 1 WLR 1241. At 1254, Lord Denning observed: 'The doctrine laid down in Salomon's case has to be watched very carefully. It has often been supposed to cast a veil over the personality of a limited company through which the courts cannot see. But that is not true. The courts can and often do draw aside the veil. They can and often do pull off the mask and look to see what really lies behind.'

37 [1974] 1 WLR 991.

38 (1985) 1 BCC 99, 421. Cumming Bruce LJ delivered the judgment of the Court of Appeal.

39 The justice criterion was also applied in Creasey v Breachwood Motors Ltd [1993] BCLC 480 and in The Tjaskemolen [1997] CLC 521. In obiter comments in Prest (n 7) 507, Baroness Hale (with whom Lord Wilson agreed) considered that successful instances of piercing the corporate veil should be viewed more simply as examples of a much broader principle based upon unconscionable advantage. This view did not, however, represent the majority opinion of the Supreme Court (discussed further in the text below).

40 See, B Maughan and S Copp, 'Piercing the Corporate Veil' (1998) New Law Journal 938 and A Walters, 'The Corporate Veil' (1998) 19 Company Law. 226.

41 Woolfson v Strathclyde Regional Council 1978 SC (HL) 90.

42 [1990] Ch 433.

43 Words taken from the judgment of Lord Keith in Woolfson v Strathclyde Regional Council 1978 SC (HL) $90,96$.

44 See n 19 above. To establish an agency relationship it is necessary to prove that the holding company exerted absolute control over the affairs of its subsidiary, see S Griffin, 'The Corporate Veil (Holding Companies and Subsidiaries)' (1991) 12 Company Law 16.

45 See the judgment of Slade LJ (n 42) 542-48

46 An ability to establish an agency relationship would make it unnecessary to pierce the corporate veil of the subsidiary. The agency relationship would deem, as of legal right, that the conduct of the subsidiary's affairs was the responsibility of its holding company. 
possible to establish an 'economic entity' relationship in circumstances where a holding company controlled the corporate policy of its subsidiary(ies). ${ }^{47}$ It is to be observed that an ability to pierce the corporate veil based on the economic entity argument fell short of the requirements necessary to establish a full agency relationship.

In commercial law cases subsequent to Adams, the evasion principle became the norm for determining whether the corporate veil could be pierced. In matrimonial cases, however, and to an objective of achieving a just and fair settlement in disputes involving the division of corporate property, the family law courts created a 'diversion' away from the evasion principle. ${ }^{48}$ This diversion empowered a spouse (ordinarily the wife) to claim that in circumstances where her husband exercised exclusive control over a company, property registered in the company's name should be construed to be the husband's property, to a conclusion that the property was matrimonial property, to which the wife could lay claim. ${ }^{49}$ The validity of the diversion was often accepted by the family courts notwithstanding that in a technical sense its application contradicted the terms of the governing legislation, namely, the Matrimonial Causes Act 1973, s 24(1)(a). ${ }^{50}$ In practice, however, the 'matrimonial law diversion' was applied sparingly because either the majority shareholder (husband) lacked effective control over the company or, alternatively, the corporate property in question was made subject to adverse third-party interests, for example, the claims of minority shareholders or corporate creditors. ${ }^{51}$ Nevertheless, it is evident that the diversion's more elastic approach, which was exemplified by the judgment of Connell J in Green v Green, ${ }^{52}$ was generally supported as a viable option for the Family Division. ${ }^{53}$

Following, however, the recent decision of the Supreme Court in Prest $v$ Petrodel Resources $L t d,{ }^{54}$ the acceptable method for determining a division of corporate property in matrimonial cases by means of piercing the corporate veil is now settled in favour of the commercial law approach. In Prest, the Supreme Court held that an order under the Matrimonial Causes Act 1973, s 24(1)(a), should not be made in relation to a division of corporate property other than where there were legitimate grounds to pierce the company's corporate veil by way of the evasion principle; or, alternatively, in circumstances where a trust had been created over the relevant property in favour of the company's controller. ${ }^{55}$ On the facts of the case, the Supreme Court found that a resulting trust had been created in favour of the controlling shareholder.

47 See e.g. Holdsworth \& Co v Caddies [1955] 1 WLR 352; Scottish Wholesale Co-op Society v Meyer [1959] AC 324; DHN Food Distributors Ltd v Tower Hamlets [1976] 1 WLR 852.

48 A number of matrimonial cases did, however, favour the evasion principle approach, see e.g. Wicks $v$ Wicks [1999] Fam 65 and Ben Hashem v Ali Shayif [2008] EWHC 2380 (Fam); [2009] 1 FLR 115.

49 The diversion takes its remit and authority from the obiter comments of the Court of Appeal in Nicholas $v$ Nicholas [1984] FLR 285, In Nicholas the corporate veil was not pierced because the husband lacked majority voting control, see the comments of Cumming-Bruce LJ, 287. It would appear that the diversion was successfully applied in only one reported case, namely Green v Green [1993] 1 FLR 326.

50 The provision provides that a wife (or husband, as the case may be) may only lay claim to her (his) spouse's property in circumstances which establish that the spouse was entitled, either in possession or reversion to the said property. If property is therefore owned and registered in a company's name the spouse will ordinarily have no entitlement to the property.

51 See e.g. Mubarak v Mubarak. [2001] 1 FLR 673.

52 See n 50 above.

53 See e.g. the comments of Mostyn J in Kremen v Agrest [2010] EWHC 3091(Fam), para 44.

54 [2013] UKSC 34; [2013] 2 AC 415.

55 See e.g. $M v M$ [2013] EWHC 2534 (Fam). 


\section{Piercing the corporate veil: the origin and development of the evasion principle}

The origin of the evasion principle is derived from the decision of the Court of Appeal in Gilford Motor Co v Horne. ${ }^{56}$ In this case, a Mr Horne, previously employed as the managing director of Gilford Motor Co $(\mathrm{G})$, left his employment (by mutual consent) to form a new company. This new company pursued a similar type of business to $G$ and, although its shareholders were nominees of Horne, the company was under Horne's dominant control. In effect, Horne's position in the new company was that of a shadow director. ${ }^{57}$ Horne's intention in forming and structuring the new company through nominees was to escape a restrictive covenant within the terms of his employment contract with $\mathrm{G}$. The restrictive covenant prohibited Horne from soliciting, interfering, or endeavouring to entice away from $G$, any person, firm or company which at any time during or at the date of the termination of his employment was a customer of or in the habit of dealing with the G.

At first instance, Farwell $\mathrm{J}$ found that the new company had been used as 'the channel through which the defendant, Horne, was carrying on his business'. ${ }^{58}$ The case was dismissed, however, because the restrictive covenant was considered to be void. On appeal, the decision of Farwell $\mathrm{J}$ was reversed and the validity of the restrictive covenant was upheld. The Court of Appeal deemed the company to have been no more than an alias of Horne. The court concluded that, as a matter of equity, the corporate veil of the company should be pierced. The restrictive covenant was enforced by means of an equitable remedy, namely, an injunction against both Horne and the company.

In Gilford, the company formed by Horne was described by Lord Hanworth MR to be no more than a 'sham, an agent' of its controller. ${ }^{59}$ Although the company was recognised as a distinct legal entity, its corporate veil was pierced to expose Horne's culpability for breaching the terms of the restrictive covenant. Horne had fraudulently sought to hide the impropriety (the breach of the restrictive covenant) behind the sham company. In Gilford, a judicial explanation of the legal relationship between Horne and the sham company, as one constituting an agency relationship, would have presented an obvious conflict with the reasoning adopted by the House of Lords in Salomon. By applying an equitable piercing principle (the evasion principle) the court neatly, although perhaps unwittingly, ${ }^{60}$ escaped any potential conflict with the approach adopted in Salomon.

The factual circumstances in Gilford that gave rise to the ultimate decision of the Court of Appeal would become the subsequent benchmark and key to unlocking the nature of a 'sham company type' scenario, a situation in which an equitable piercing of the corporate veil would be justified. Yet, following the decision in Gilford and for the next 30 years, there were no reported cases in which the evasion principle was successfully

56 [1933] Ch 935. The Court of Appeal (see the judgment of Lord Hanworth, 961) adopted the reasoning applied in Smith v Hancock [1894] 2 Ch 377. The exact principle enunciated in Smith was that if a valid restrictive covenant prevented the vendor of a business from setting up a competing business, then it would also be valid to prevent the vendor retaining an interest in a competing business operated by his wife, a close relative or associate.

57 See, CA 2006, s 251. A shadow director may be defined as a person who often operates outside the internal management structures of a company but who is, nevertheless, able to exert significant influence over a part or whole of the company's affairs. The advice and instructions of this person are usually followed by the company's board of directors. See Secretary of State v Deverell [2001] Ch 340.

58 See Gilford (n 56) 943.

59 See the judgment of Lord Hanworth MR, ibid 961-62.

60 The decision of the House of Lords in Salomon (n 1) was not considered in the judgment at first instance, or in the judgment of the Court of Appeal. 
applied. The first case after Gilford to apply the evasion principle was Jones $v$ Lipman. ${ }^{61}$ Here, a Mr Lipman sought to escape specific performance of a contract for the sale of land. Lipman attempted to evade the contract by transferring the land in question to a company which he had recently acquired. ${ }^{62}$ Russell $\mathrm{J}$ held that the company was used as a device to evade Lipman's contractual responsibility; specific performance for the sale of the land was granted against both Lipman and the company. By seeking to evade the purchase contract Lipman had sought to evade an existing legal obligation, an impropriety that he had then attempted to hide behind the corporate veil of a newly acquired company to an objective of frustrating the contract of sale. The evasion principle was applied and the company's corporate veil was pierced to expose Lipman's personal culpability. Russell J commented that:

The defendant company is the creature of the first defendant, a device and a sham, a mask which he holds before his face in an attempt to avoid recognition by the eye of equity. ${ }^{63}$

Subsequent to the decision in Jones $v$ Lipman, cases portraying factual circumstances to justify the application of the evasion principle were a great rarity. Indeed, the correct usage of the evasion principle would be applied successfully in but one instance, namely the decision of Foster J in Locke (Albert) (1940) $v$ Winsford Urban DC. ${ }^{64}$ Although both Gencor ACP Ltd v Dalby ${ }^{65}$ and Trustor $A B v$ Smallbone (No2) ${ }^{66}$ would provide linkage to the evasion principle, in so far as both cases purported to adopt and apply the principle, in reality, the exact and precise elements that properly identify the evasion principle were absent in both cases. In both Gencor and Trustor the controller of a company committed an impropriety by breaching a fiduciary duty to a third party, ${ }^{67}$ but, contrary to a strict adherence to the evasion principle, the said impropriety was not hidden behind the corporate veil of the sham company. The breach of duty to the third party and the consequences attached to the breach existed quite independently of the involvement of

61 [1962] 1 WLR 832. The decision did not incorporate any form of agency analogy.

62 This was an 'off the shelf' company which had a legal existence at the date of the sale contract, i.e. technically, the company had not been incorporated with a specific intention of impugning the sale contract. Nevertheless, following its creation, the company's first commercial use was as a fraudulent device.

63 See Lipman (n 61) 836.

64 (1973) 71 LGR 308. Here, the corporate veil of a newly incorporated company was pierced to prevent its shareholders from using the company as a means to breach the terms of a restrictive covenant. The shareholders had entered into the restrictive covenant prior to the incorporation of the company.

65 [2000] 2 BCLC 734 In Gencor, D, the former managing director of a group of companies (G), acted in breach of his fiduciary duty by dishonestly diverting assets and business opportunities away from $G$ to a recently incorporated company which was under D's control. The company had been incorporated with no independent business activity save as to function as D's offshore bank account. Rimer J held that the corporate veil of this company should be pierced and its assets treated as if they were personally held by $\mathrm{D}$. D was held liable to account to $\mathrm{G}$.

66 [2001] 1 WLR 1177. In Trustor, S, the former managing director of a company (T), in breach of his fiduciary duty to $\mathrm{T}$, procured large sums of its money and paid the same to a company (I) over which $\mathrm{S}$ exerted control. At an earlier stage of the litigation, $T$ obtained summary judgment on claims against $I$ on the ground that it had acted as a constructive trustee in the knowing receipt of the unauthorised payments. Thereafter, $T$ made a subsequent application for summary judgment against $\mathrm{S}$ personally, on the ground that he was also liable to account as a constructive trustee. To establish S's liability, the court pierced the corporate veil of I, to a conclusion that I's knowledge could be attributed to S, therefore establishing S's personal receipt of the money as a constructive trustee.

67 In Trustor, ibid, the company (I) had not been incorporated with a specific intention of hiding the impropriety, i.e. the company was already in existence at the time the impropriety was committed. The incorporation of I appeared, however, to serve no legitimate business purpose. 
the respective sham companies. ${ }^{68}$ In reality, in both Trustor and Gencor, the corporate veil of the respective sham companies was pierced to ensure that a third party's claim for the sum of misappropriated funds was enforceable. In the context of the relevant improprieties in both Gencor and Trustor, the scope of the evasion principle was extended to cover a monetary loss, traceable directly to the actual impropriety (the breach of duty), a monetary sum that was subsequently hidden behind the corporate veil. In common, however, with the cases of both Gilford and Jones, the respective companies in Trustor and Gencor were both incorporated to an ultimate objective of pursuing an illegitimate purpose to the benefit of their respective controllers.

\section{THE RELEVANCE OF THE EVASION PRINCIPLE IN A HOLDING COMPANY-SUBSIDIARY RELATIONSHIP}

In the context of a holding company-subsidiary relationship, there is, to date, no case example which portrays the correct application of the evasion principle. The decision of the Court of Appeal in Coles v Samuel Smith Old Brewery (Tadcaster) ${ }^{69}$ may, however, represent an implied, albeit technically incorrect application of the evasion principle. In Coles, the Court of Appeal held that a landlord of leasehold property could not avoid the right of the tenants of that property to exercise an option to purchase the property (the preexisting obligation). The landlord sought to avoid its obligation by selling and transferring the property to its subsidiary company for value (although at a much-discounted price). While the subsidiary company was not legally bound by the option (the option had not been registered), nevertheless, the Court of Appeal ordered specific performance against the original landlord; in so far as the landlord, as the controller of the subsidiary company, had the power to compel the subsidiary to abide by the order for specific performance. Here, it would be an exaggeration to suggest that the court applied the evasion principle in strict accordance with its accepted definition. Indeed, in Coles, the court considered that the subsidiary company was not a sham because its incorporation had not been designed to impugn an existing legal obligation of its controller (the holding company).

In all other corporate group cases in which the courts have considered disturbing corporate personality, the courts' common conclusion has been that the evasion principle could not be applied. For example, in Ord $v$ Bellhaven Public Houses Ltd $^{70}$ the plaintiff acquired a 20 -year lease for a public house from the defendant company; the defendant was one of a number of subsidiaries of a holding company. The lease was taken in reliance of the defendant's alleged misrepresentation relating to the turnover and profitability of the public house. Prior to the trial of the proceedings, the defendant's assets were transferred to other companies within its corporate group. The holding company contended that the transfer of the funds was essential to the restructuring of the group. The plaintiff sought to pierce the corporate veil of the defendant on the basis that it and the other companies in the group were controlled by its holding company in the manner of a single economic entity. In respect of the single economic entity argument and following its own decision in Adams v Cape Industries, the Court of Appeal refused to disturb the corporate veil of the defendant. The court further held that the evasion principle could not be applied because the defendant company had not been incorporated to impugn a pre-existing duty or obligation of its controlling shareholder (the holding

68 This point is advanced in the judgment of Lord Sumption in Prest (n 7) 485-86 (discussed in the text below).

69 [2008] 2 EGLR 159.

$70 \quad[1998] 2$ BCLC 477. 
company). The pre-existing obligation properly belonged to the defendant company and not its holding company.

The decision of the Court of Appeal in Yukong Lines Ltd of Korea $v$ Rendsburg Investment ${ }^{71}$ also highlights the fact that the evasion principle cannot be applied even to a situation where a holding company (or, as in Yukong, an individual in control of a group of companies) intentionally manipulates a group structure with the specific and dominant intention of avoiding an existing obligation of a company within that group. In Yukong, the defendant company (D) transferred a majority of its funds to another company within its group structure, leaving $\mathrm{D}$ with insufficient assets to compensate a third party for the repudiation of charter party contract, a contract which had been repudiated on the very day when the funds had been transferred to the other company. Toulson $J$ held that the corporate veil of $\mathrm{D}$ could not be pierced by applying the evasion principle in so far as the contract had not been entered into by $\mathrm{D}$ with a view to defeating any pre-existing obligation of its controlling shareholder. While the controller of $\mathrm{D}$ used another company within the group of companies under his control to, in effect, escape D's contractual obligation, the pre-existing obligation properly belonged to $\mathrm{D}$ and not its controller.

\section{Piercing the corporate veil outside the evasion principle: the fraudulent incorporation concept}

In some commercial judgments, both pre- and post-Adams, a deviation away from the strict confines of the evasion principle is evident in the form of an implied acceptance of the fraudulent incorporation concept. ${ }^{72}$ Although the courts have never sought to expressly identify or define this concept, it is suggested that relevant case law (discussed below) may be interpreted to formalise its definition. The concept may be explained in the following manner, namely that the corporate veil may be pierced in a situation where a company was incorporated by its controller with the specific and dominant intention of pursuing a fraudulent business purpose. In such cases, an intention to defraud may be established in circumstances where the company's controller was aware, or by the notions of ordinary decent business people should have been aware, that the company's incorporation was not to a dominant purpose of pursuing a bona fide commercial activity but rather that its incorporation sought to abuse the incorporation process to the financial advantage of its controller and to the detriment of a third party(ies).

Indeed, the factual circumstances of the very cases which form the basis of the evasion principle, namely Gilford and Lipman, fall within the fraudulent incorporation concept. In both Gilford and Lipman, the company subject to the veil-piercing was created with the specific intention of fraudulently exploiting the incorporation process to the financial advantage of its controller and, on the basis of this explanation, the cases of Gencor ACP Ltd v Dalby ${ }^{73}$ and Trustor AB v Smallbone (No 2) ${ }^{74}$ also fall within the fraudulent

71 [1998] BCC 870.

72 In Creasey v Breachwood Motors Ltd [1993] BCLC 480, in the context of a group of companies, Richard Southwell QC, sitting as a deputy High Court judge, deviated away from a strict adherence to the evasion principle not by applying the fraudulent incorporation concept, but instead by resting his decision on the justice of the particular case. The spirit of this 'justice deviation' was followed by Clarke J in The Tjaskemolen (n 39). Creasey was subsequently distinguished in Yukong Lines Ltd of Korea v Rendsburg Investments [1998] BCC 870 , on the basis that the 'justice approach' was inconsistent with the reasoning advanced in Adams v Cape Industries. Creasey was overruled subsequently by the Court of Appeal in Ordv Bellhaven [1998] 2 BCLC 477.

73 [2000] 2 BCLC 734.

74 Trustor (n 66) 
incorporation concept. The fraudulent incorporation concept would also apply in a corporate group situation where, for example, the controller of a group of companies incorporated an additional company within the group to the specific objective of transferring an existing liability from one of the existing companies within the group to the newly incorporated company. In corporate group cases of a type similar to Ord $v$ Bellhaven Public Houses Ltd ${ }^{75}$ and Yukong Lines Ltd of Korea $v$ Rendsburg Investments, ${ }^{76}$ it would not, however, be possible to apply the fraudulent incorporation concept given that in such cases the relevant subsidiary company would have been initially incorporated to pursue a legitimate business purpose. Here, an ability to pierce the corporate veil of the relevant subsidiary company would be dependent upon extending the fraudulent incorporation concept. The concept would have to be extended so that it applied in circumstances where, following its incorporation and initial use as a legitimate enterprise, the relevant subsidiary company was intentionally used for a fraudulent purpose in abuse of its limited liability status.

\section{APPLYING THE FRAUDULENT INCORPORATION CONCEPT}

The fraudulent incorporation concept does not operate within the strict confines of the evasion principle and, crucially, may be invoked to pierce the corporate veil without the necessity of establishing that the controller of a company used that company for the specific purpose of evading a pre-existing legal obligation. Interestingly, the implied application of the fraudulent incorporation concept actually preceded the courts' acceptance of the evasion principle. The fraudulent incorporation concept was impliedly invoked in Re Darby exparte Brougham. ${ }^{77}$ In Re Darby, Phillimore J had to determine whether either the City of London Investment Corporation (C) or the actual controllers of $\mathrm{C}$ undertook the fraudulent promotion of a company, Welsh Slate Quarries Ltd (W). On the facts of the case, Phillimore $\mathrm{J}$ held that $\mathrm{C}$ was no more than an alias of its two controllers, a Mr Darby and a Mr Gyde. The intention of Darby and Gyde had been to incorporate C to exploit and abuse the incorporation process to their financial advantage, an intention enacted through C's fraudulent promotion of $\mathrm{W}^{78}$ The learned judge concluded that the responsibility for the fraudulent promotion of $\mathrm{W}$ properly rested with Darby and Gyde. Based on this intentional fraud, the corporate veil of $\mathrm{C}$ was lifted in its entirety to the extent that Darby was made personally liable in damages. ${ }^{79}$ In Darby, the Salomon case was cited, but correctly distinguished on its facts because in Salomon the company had not been incorporated with the intention of perpetrating a fraud. In Darby, the evidence was conclusive to the contrary. The controllers of $\mathrm{C}$ incorporated the company with the sole intention of committing a fraud, a fraud which materialised in the promotion of $\mathrm{W}$.

Notwithstanding an obvious logic and desire to combat the fraudulent exploitation of the corporate form, the fraudulent incorporation concept has never been formally recognised by the courts. In case law subsequent to Re Darby, the concept has been surpassed, in the alternative, by a rigid acceptance of the correctness of the evasion principle. Nevertheless, in a limited number of subsequent cases (discussed below) in which the corporate veil was pierced, the technical requirements of the evasion principle were never met. In such cases, it is contended that a piercing of the corporate veil may be better explained by the application of the fraudulent incorporation concept. For

75 See Ord v Bellhaven (n 70).

76 See ibid.

77 [1911] 1 KB 95.

78 C was incorporated in October 1903. The fraudulent promotion of W occurred in November 1904.

79 At the time of the proceedings, Mr Gyde had been declared bankrupt. 
example, an implied application of the fraudulent incorporation concept was implicit in the decision of the High Court of Justiciary (Sc) in Drew v HM Advocate. ${ }^{80}$ Here, a Mr Drew formed a company for the sole purpose of fraudulently obtaining credit to the benefit of himself. In piercing the company's corporate veil, the court held that the company was a mere device to conceal the true state of affairs. Drew was deemed liable for the fraudulent acts carried out in the company's name. In reaching its decision, the court purported to apply the evasion principle. In reality, however, Drew never sought to hide a pre-existing obligation behind the corporate veil of the sham company. Accordingly, a specific requirement of the evasion principle was never met.

A further example of an affirmative, albeit implied application of the fraudulent incorporation concept is found in Kensington International Ltd $v$ Republic of Congo and Others. ${ }^{81}$ Here the claimant, a judgment creditor, obtained four judgments against the Republic of the Congo in relation to sums due under various loan and credit agreements. The claimant obtained interim third-party debt orders in each of the four actions in which judgment had been obtained together with supporting injunctions relating to the monies due in respect of two consignments of Congolese oil which had been purchased by a third party from a company controlled by the Republic of Congo. Cooke J held that the third party's debt to the company for its purchase of the consignments of oil should be viewed as a debt owed to the Republic of Congo and therefore should be treated as part of the Republic of Congo's debt to the claimant. Here, the corporate veil of the company under the control of the Republic of Congo was pierced, lifted in its entirety on the premise that the company's incorporation had been dishonestly procured with the intention and sole purpose of permitting the Republic of Congo to escape its creditors. As in Drew, in Kensington International, the evasion principle could not have been applied; the Republic of Congo had never sought to hide a pre-existing obligation to $\mathrm{K}$ behind the corporate veil of the sham company.

Further examples of an implied use of the fraudulent incorporation concept are most apparent in cases of a similar type to Gencor ACP Ltd v Dalby, 82 namely cases in which the corporate veil was pierced in circumstances involving a fiduciary's breach of the conflict of interest duty. ${ }^{83}$ As a result of breaching the conflict of interest duty, a fiduciary is ordinarily liable to return to the victim company any profit he or she personally made as a consequence of the breach. ${ }^{84}$ Where, however, the fiduciary exploits the conflict of interest through a sham company, the fiduciary will, in a technical sense, attain no personal benefit from the breach. By adhering strictly to the Salomon principle, the 'fruits' of the breach will properly belong to the sham company. In such circumstances, the sham company, as a constructive trustee, will be accountable to the victim company for the return of any profit made. If, however, the sham company cannot discharge its liability, the victim company's ability to recover the fruits of the breach will be dependent on

801995 SCCR 647; 1996 SLT 1062.

81 [2005] EWHC 2684 (Comm); [2006] 2 BCLC 296.

82 See Gencor (n 65)

83 See e.g. Shell International Trading v Tikhonov [2010] EWHC 1399 (Ch); CMS Dolphin Ltd v Simonet [2001] 2 BCLC 704.

84 The conflict of interest duty is now governed by CA 2006, ss 175-77. Prior to the codification of directors' duties by the CA 2006, transactions involving a conflict of interest were regulated as a rule of equity, see e.g. Regal Hastings Ltd v Gulliver [1967] 2 AC 134. This equitable rule was applied strictly and its strict interpretation is incorporated into the terms of CA 2006, ss 175-77, see e.g. Towers v Premier Waste Management Ltd [2012] BCC 72. In its simplest form the conflict of interest duty may be described as a duty of loyalty and fidelity which prohibits a director of a company from exploiting a corporate opportunity, corporate property, corporate information or his/her own corporate position, to his/her own potential advantage. 
overturning the Salomon principle - namely the victim company will require judgment against the fiduciary. In such circumstances the fiduciary cannot hide the breach of duty (an existing legal obligation) behind the corporate veil of the sham company. ${ }^{85}$ The ability to pierce the corporate veil cannot be explained by the evasion principle. Accordingly, it is submitted that in such cases the ability to pierce the corporate veil of the sham company can only be explained by accepting that the piercing was achieved impliedly through the fraudulent incorporation concept.

An example, significant to the implied use of the fraudulent incorporation concept in circumstances where a fiduciary acted in breach of the conflict of interest duty, is found in the judgment of Burton J in Antonio Gramsci Shipping Corporation v Stepanovs. ${ }^{86}$ In Gramsci $v$ Stepanovs, the claimant ship owners (C) held shares in a company (LSC) which had been incorporated to enter into shipping contracts for the benefit of C. S, a senior executive of LSC (together with other executive members of LSC), 87 subsequently incorporated distinct sham companies with the sole and dishonest objective of diverting corporate opportunities (shipping contracts) away from LSC. S, acting in breach of the conflict of interest duty to LSC, achieved this objective by chartering a number of vessels to the sham companies on charter parties at less than the market rate and then subsequently sub-chartering the vessels through the sham companies to third parties at the market rate; thereby depriving LSC (ultimately C) of the difference between the market rate and the charter rates achieved by LSC. In effect, the sham companies creamed off a substantial amount of the profits which should have been destined for LSC. Burton J pierced the corporate veils of the sham companies ${ }^{88}$ to a conclusion that both they and their controlling shareholder (S) were liable to LSC in damages. In determining the issue, Burton J relied heavily on the judgment of Sir Andrew Morritt VC in Trustor $v A B$ Smallbone (No 2). ${ }^{89}$ Yet, as previously contended in this paper, the reasoning of Morritt VC did not follow a strict allegiance to the evasion principle, ${ }^{90}$ but rather, it is submitted, should be better regarded as an example of piercing the corporate veil by way of the fraudulent incorporation concept.

Indeed, in piercing the corporate veils of the sham companies, Burton J refused expressly to be shackled by the technical constraints of the evasion principle. ${ }^{91}$ The

85 See Prest (n 7).

86 [2011] EWHC 333 (Comm); [2012] 1 All ER 293. The case determined whether a claimant could establish jurisdiction in the English courts by virtue of a jurisdictional clause. Burton $J$ answered the question in the affirmative and as such issues relating to the court's ability to pierce the corporate veil became relevant. The findings of Burton $\mathrm{J}$ on the jurisdiction point were subsequently reversed, see Antonio Gramsci Shipping Corporation and Others v Aivars Lembergs [2013] EWCA Civ 730; [2014] 1 BCLC 581.

$87 \mathrm{C}$ was not obliged to show that $\mathrm{S}$ was in sole control of the sham companies in so far as there were a number of wrongdoers, all who shared a common purpose of exploiting LSC.

88 The sham companies were the contracting parties that entered into the fraudulent scheme, technically the impropriety did not belong to $\mathrm{S}$ and, to follow the strict and arbitrary requirements of the evasion principle, the corporate veils of the sham companies should have remained intact, see e.g. Aerostar Maintenance International Ltd v Wilson [2010] EWCH 2032.

89 Trustor (n 66) 1185. Morritt VC purported to apply the evasion principle. The VC stated: 'In my judgment the court is entitled to pierce the corporate veil and recognise the receipt of the company as that of the individual(s) in control of it if the company was used as a device or façade to conceal the true facts, thereby avoiding or concealing any liability of those individuals.'

90 In a technical sense the impropriety in question (breach of duty) was not hidden behind the corporate veils of the sham companies.

91 [2011] EWHC 333 (Comm); [2012] 1 All ER 293, 303-06. 
learned judge also sought to distinguish the decisions of both Warren J in Dadourian Group International Inc $v$ Simms ${ }^{92}$ and Flaux J in Lindsay v O'Loughnane ${ }^{93}$ where, in both cases, it was held that that a controlling shareholder of a company could never be found liable for a breach of contract in circumstances where the offending contract was entered into by the company as a distinct legal person. In analysing the judgments in both Dadourian and Lindsay, Burton J considered that it had not been appropriate for either court to establish the controlling shareholder's liability as a breach of contract because in both cases the controlling shareholder had already been found personally liable in tort. ${ }^{94}$

The reasoning and decision of Burton $\mathrm{J}$ in respect of both the corporate veil point and the breach of contract issue was, however, to be subsequently overruled by the Court of Appeal in VTB Capital plc v Nutritek. ${ }^{95}$ A further decision of Burton J in Alliance Bank JSC v Aquanta Corporation, ${ }^{96}$ in which Burton J relied upon the accuracy of his own analysis in Gramsci v Stepanovs, was also overruled. The decision to overrule Burton J may be explained on the basis that the court accepted the absolute and perceived correctness of the evasion principle.

\section{The evasion principle in absolute ascendancy}

The ascendancy, authority and judicially perceived correctness of the evasion principle was confirmed by two recent decisions of the Supreme Court, namely VTB Capital plc v Nutritek ${ }^{97}$ and Prest $v$ Petrodel Resources Ltd. ${ }^{98}$ In the former case, two specific issues had to be determined. The first and central issue concerned one of jurisdiction, namely whether the trial of the issues should be held in Russia or England. ${ }^{99}$ The Supreme Court (Lord Clarke and Lord Reed JJSC dissenting) concluded that the trial should proceed in Russia. The second issue, namely whether the claimant should be allowed to raise an additional claim involving issues relevant to a piercing of the corporate veil, was superseded by the outcome of the first claim. The Supreme Court sought, however, to consider the significance of the piercing claim.

In relation to the factual circumstances surrounding the piercing issue, the claimant bank, VTB Capital (VTB) entered into a loan agreement with a Russian company (C). C defaulted on the loan agreement and VTB sought to pierce the corporate veil of $\mathrm{C}$ to make C's controlling shareholder (D4) liable for the default. The significance of the loan agreement was that it had allowed $C$ to fund acquisitions from a company (D1) which was

92 [2009] EWCA Civ 1327.

93 [2010] EWHC 529 (QB).

94 Trustor (n 66) 302-04. In both Dadourian and Lindsay, the courts explained, however, that the correct basis upon which to pierce the corporate veil was in a situation where the company was used by its controller in an attempt to immunise a liability for a wrongdoing existing entirely dehors the company. In Gramsci, the wrongdoing was not dehors the sham companies in so far as it had been perpetrated in the name of the sham companies.

95 [2012] EWCA Civ 808; [2012] 2 BCLC 437, a decision affirmed by the Supreme Court in VTB Capital v Nutritek [2013] UKSC 5, [2013] 2 AC 337.

96 [2011] EWHC (Comm) 3281.

97 See VTB Capital (n 95).

98 Prest (n 7).

99 The central question for the Supreme Court was one of jurisdiction. While the law governing the alleged torts was English law, that factor had less force because the issues were factual rather than legal. As the fundamental factual focus was on Russia and the Russian witnesses, the Russian connection was of such strength that the Supreme Court held (Lord Clarke and Lord Reed JJSC dissenting) that the claimant could not discharge the onus of establishing that England was the appropriate forum for trial. For an interesting critique of this outcome see, A Briggs, 'The Subtle Variety of Jurisdiction Agreements' (2012) Lloyd's Maritime and Commercial Law Quarterly 364. 
a part of the same corporate group as C. C obtained the loan agreement by way of a fraudulent misrepresentation by D1. While D1 was not a party to the contract with VTB, it was alleged by VTB that $\mathrm{C}$ had been used as a device to conceal the true facts, namely that $\mathrm{C}$ and $\mathrm{D} 1$ were members of a related group of companies which were all under the control of D4. VTB asserted that the corporate veil of $\mathrm{C}$ should be pierced to establish that D4 had the ultimate responsibility for the breach of the loan agreement. To support the piercing argument, counsel for the claimant relied specifically on the decisions of Burton J in Gramsci v Stepanovs ${ }^{100}$ and Cooke J in Kensington International Ltd $v$ Republic of the Congo. ${ }^{101}$ To counter the claimant's argument, defence counsel sought to deny the very legitimacy of a piercing principle maintaining that, at common law, there was no juridical basis for a freestanding principle of lifting (piercing) the corporate veil and that such a principle ran contrary to the decision of the House of Lords in Salomon. ${ }^{102}$

In judgment, the Supreme Court found that, had it been necessary to decide the 'piercing issue', it would have concluded that the corporate veil of $\mathrm{C}$ should not have been pierced. Indeed, Lord Neuberger, giving the leading judgment on the corporate veil point, conveyed some sympathy with defence counsel's argument for denying the legitimacy of a 'piercing principle'. ${ }^{103}$ On the facts of the case, however, Lord Neuberger considered it unnecessary and inappropriate to resolve the issue. His Lordship considered more generally that it was correct for the law to permit the corporate veil to be pierced to an objective of defeating a well-versed form of injustice, a fraud which was of the type and nature associated with the application of the evasion principle. It is to be observed that, had the Supreme Court deemed it necessary to apply the evasion principle to the factual circumstances of the case, the principle would not have applied because, although D4 controlled C, C had not been used by D4 to the specific purpose of evading a pre-existing obligation/duty of D4. In law, the obligation/duty belonged properly to C. Further, Lord Neuberger found that, even if the corporate veil could have been pierced, D4 could not have been sued on a contract to which he was not a party. ${ }^{104}$ In criticising the decision in Gramsci, Lord Neuberger stated that:

I doubt that the decision in Gramsici can be justified, at least on the basis of piercing the corporate veil. In agreement with the Court of Appeal and Arnold J, I think that the reasoning in that case involved a misinterpretation of the basis of the decisions in Gilford and Jones. It seems to me that the conclusion in Gramsci was driven by an understandable desire to ensure that an individual who appears to have been the moving spirit behind a dishonourable (or worse) transaction, action, or receipt, should not be able to avoid liability by relying on

100 [2011] EWHC 333 (Comm); [2012] 1 All ER 293.

101 [2009] AC 1391.

102 Defence counsel submitted that where an actual piercing principle had been applied, it was either accepted erroneously as common ground that the principle actually existed and/or the result achieved by piercing the veil of incorporation could have been achieved by a less controversial route - for instance, through the law of agency, through statutory interpretation, or on the basis that money due to an individual which he then directs to his company is to be treated as received by him personally. Of the minority of cases supporting the existence of a piercing principle that are without any tangible link to a relevant rule of law, counsel suggested that these cases were not based soundly in authority.

103 VTB Capital (n 95) 382-85. Lord Wilson (391) considered that the defence counsel's submission was 'highly ambitious'.

104 Ibid 382-85. The claimants contended that the claim in contract was analogous to the position of the controlling shareholder being treated as an undisclosed principal. Yet an undisclosed principal cannot sue nor be sued unless the agent entered into the contract on the undisclosed principal's behalf and did so with his or her authority. In VTB Capital, there was never any suggestion that the controlling shareholder had authorised the company to enter into contracts on his behalf. 
the fact that the transaction, action, or receipt was effected through the medium (but not the agency) of a company. But that is not, on any view, enough to justify piercing the corporate veil for the purpose of holding the individual liable for the transaction, action, or receipt, especially where the action is entering into a contract. ${ }^{105}$

In relation to the facts found in VTB Capital and in the context of following a strict interpretation of the evasion principle, the correctness attached to the commentary of Lord Neuberger is beyond doubt. Nevertheless, an obvious and significant difference between Gramsci and VTB Capital was that the former case met the fundamental requirement of the fraudulent incorporation concept, namely the company had been incorporated specifically to the object of committing a fraud. Indeed, prior to the Supreme Court's decision in VTB Capital, the decision in Gramsci had been distinguished (but not disputed) by Flaux J in Lisen International Ltd $v$ Humpuss Sea Transport Ltd. ${ }^{106}$ As in VTB Capital, in Lisen, the company in question had not been incorporated with the specific intention of committing a fraud. ${ }^{107}$ Further, it is poignant to observe that in VTB Capital, Lord Clarke portrayed some reluctance in accepting that the outcome reached in Gramsci had been in error. Lord Clarke stated:

I agree with Lord Neuberger that this is not a case in which it would be appropriate to pierce the corporate veil on the facts. I would however wish to reserve for future decision the question what is the true scope of the circumstances in which it is permissible to pierce the corporate veil. That includes the question whether Antonio Gramsci Shipping Corpn v. Stepanovs [2011] EWHC 333 (Comm) was correctly decided. ${ }^{108}$

It is suggested that the justification for Lord Clarke's observation and implied acceptance of an ability to pierce the corporate veil outside the strict confines of the evasion principle, namely in circumstances where a company was incorporated by its controller to an objective of committing a fraud, supports the very basis of a fraudulent incorporation concept.

It is submitted that more crucial to the observations of the Supreme Court in VTB Capital was the finding that a remedy in contractual damages could not be sustained against a non-contracting party. Yet, the ability to disturb corporate personality in accordance with the fraudulent incorporation concept would overturn the privity point. In piercing the corporate veil by applying the fraudulent incorporation concept, the controller of the sham company, as opposed to the company itself, would be deemed to have been personally responsible for entering into a contract. For example, had the facts in Salomon established an intentional fraud akin to that found in the fraudulent incorporation cases, then it is most probable that a majority of the House of Lords would have followed the lead of the lower courts to disturb the corporate veil of A Salomon \& Co Ltd. As such, Mr Salomon would have been held personally liable for the nonpayment of sums due on the contractual debts of the company's unsecured creditors, notwithstanding that the contracts creating such debts were formally entered into in the company's name.

105 VTB Capital (n 95) 387.

106 [2011] EWCH 2339.

107 In Lisen (ibid para 18), Flaux J suggested that, if the purpose behind the corporate structure had been to perpetrate a fraud, then, in such circumstances, it should not have been necessary to establish the wrongdoing as dehors the company.

108 VTB Capital (n 95) 413. 


\section{The 'concealment' and 'evasion' labels}

In Prest v Petrodel Resources Ltd, ${ }^{109}$ the Supreme Court was again called upon to consider issues relevant to an ability to pierce the corporate veil. As in VTB Capital, the Supreme Court's analysis of the corporate veil point did not form part of the ratio of its decision. ${ }^{110}$ In Prest, however, the theoretical analysis of the 'veil point' was most significant and in a substantial part contentious. The individual judgments, analysis and reasoning of the Supreme Court were, in part, diverse in respect of defining the exact scope of an acceptable piercing principle. With the exception of Lord Walker, the court accepted, however, that it was possible, as a last resort, to pierce the corporate veil in circumstances justifying the application of the evasion principle. ${ }^{111}$ For his part, Lord Walker was steadfast to the conclusion that piercing the corporate veil was not a doctrine or coherent principle or rule of law, but simply a label which had often been used indiscriminately to describe the disparate occasions on which some rule of law produced an apparent exception to the Salomon principle. ${ }^{112}$

Lord Neuberger and Lord Sumption delivered the most extensive judgments on the corporate veil point, identifying two distinct categories of 'piercing cases', namely 'concealment cases' and 'evasion cases'. A concealment case involved the application of conventional legal principles, the effect of which would override an arrangement whereby a company had been interposed for the benefit of an individual, to an objective of disguising the true nature of that arrangement. ${ }^{113}$ The application of the relevant legal principle culminated in the conclusion that the arrangement should have been construed as one made with the individual and not the company. In contrast, an evasion case invoked a 'true' and distinct 'piercing principle'. In construing this latter principle, Lord Neuberger accepted Lord Sumption's definition of an evasion case, namely an evasion case would exist in circumstances where:

... a person is under an existing legal obligation or liability or subject to an existing legal restriction which he deliberately evades or whose enforcement he deliberately frustrates by interposing a company under his control. ${ }^{114}$

Although Lord Neuberger accepted the evasion principle with some reluctance, his Lordship considered that it should be retained as a limited form of judicial tool, to be used sparingly as a last resort, to undo wrongdoing in a situation where no other legal

109 Prest (n 7).

110 The issue in Prest (n 7) related to the potential division and ownership of seven properties. Although the properties in question were held by distinct companies, all of which were under the control of the husband, the wife contended that the properties should be treated as matrimonial assets. The Supreme Court was required to consider whether it was possible to pierce the corporate veils of the companies under the husband's control. The court held in favour of the wife but did so other than by applying a piercing principle

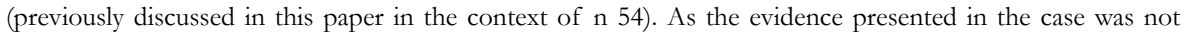
conclusive to the finding of a valid legal transfer of the properties from the husband to the companies under his control, the court held that no evidence had been adduced to rebut a presumption that the companies took the properties as a resulting trustee for the husband. The husband was ordered to convey the disputed properties to his wife on the basis that they belonged to him beneficially by way of a resulting trust.

111 This followed the opinion expressed by Munby J in Ben Hashem v Al Shayif [2009] 1 FLR 115, i.e. the court only has power to pierce the corporate veil when all other more conventional legal remedies have proved to be of no assistance.

112 Prest (n 7) 508.

113 The concealment principle was subsequently and expressly applied by Havelock-Allan $\mathrm{J}$ in Airbus Operations Ltd $v$ Withey [2014] EWHC 1126 (QB). From the judgment in this case it is unclear, however, whether the concealment principle was invoked on the basis of either agency or trust law principles.

114 Prest (n 7) 487. 
principle could be applied to remedy the situation. Lord Neuberger concluded that cases in which the evasion principle had previously been applied were, however, either wrongly decided or could and should have been explained as concealment cases. ${ }^{115}$ For example, Lord Neuberger explained that the outcome in the Gilford case should have been decided by solely applying agency law principles. In relation to Jones $v$ Lipman, Lord Neuberger found that it had been unnecessary for Russell $\mathrm{J}$ to invoke a piercing doctrine because an order for specific performance made specifically against Mr Lipman would have sufficed. Lipman was in a position to have compelled the company to convey the property to the plaintiffs and would have been bound to do everything that was reasonably within his power to ensure that the property was conveyed. ${ }^{116}$

While Lord Neuberger declined to accept that the evasion principle had been established by previous case law, Lord Sumption considered that the 'principle', although lacking any general doctrine, was well established in English case law. ${ }^{117}$ Nevertheless, Lord Sumption conceded that the outcome of previous piercing cases could often have been achieved by applying the concealment principle. ${ }^{118}$ In relation to the cases of Gencor and Trustor, Lord Sumption considered that these cases should be viewed as concealment cases. Lord Sumption contended that, in both Gencor and Trustor, the evasion principle had not been properly engaged and could not have been engaged on the case facts because in both cases a company's separate legal personality had not been used to evade an existing liability of its controller. The controllers of the respective companies were therefore liable to account only if the true facts were that the company had received the money as their agent or nominee. That was proved in both cases for, if it had been otherwise, there would have been no receipt, knowing or otherwise, and therefore no claim to be evaded. ${ }^{119}$

Although the introduction of the concealment and evasion labels was a novel development in the classification of the piercing-type cases, it is submitted, however, that the classification cannot be considered as conclusive. The labels fail to explain properly those cases in which the corporate veil was pierced by another means, namely by impliedly invoking the fraudulent incorporation concept. Further, while it may have been plausible in part for Lord Sumption and Lord Neuberger to suggest that in previous piercing cases the courts should, in the alternative, have applied a relevant legal principle to disturb corporate personality, the implied or express refusal to adopt this course of action may be explained other than by a failure on the part of the respective courts to identify or apply the relevant legal principle in question. Other than the legal principle alluded to by Lord Neuberger in Lipman, ${ }^{120}$ the predominant relevant legal principle advanced as an alternative to the evasion principle was one of agency or trust law, the application of such principles having been denied unequivocally by the House of Lords in Salomon.

In the context of applying agency principles to justify the concealment principle and other than in a holding company-subsidiary company relationship, it is submitted that the

115 Prest (n 7) 511-03.

116 Ibid.

117 Ibid 484. Lord Clarke agreed with Lord Sumption on this point, at 507.

118 Ibid 485-86.

119 Ibid 487.

120 In relation to the Lipman case (n 61), while Mr Lipman as the controlling shareholder of the company had a power to compel the company to abide by the terms of the order for specific performance, as a matter of pure legal certainty and to eliminate any future defect in the use of Mr Lipman's power, it is nevertheless contended that the decision to pierce the corporate veil and subject the company to the grant of specific performance was the preferred and correct course of action. 
ability to label a company as the agent of its controlling shareholder would open the floodgates to challenge the very purpose behind incorporating small one-man-type concerns. This type of company benefits from the business incentives provided by the separation of identity and responsibility between the controlling shareholder and corporate entity. Further, such incentives are not only beneficial to the controlling shareholder as they may also confer a potential future benefit to the economy and general public interest in the expectation of a company's future growth and expansion. The argument that a small one-man-type company should not be considered as the agent of its controlling shareholder follows the judgment in Salomon and also the lead of Rimmer LJ who, in the Court of Appeal judgment in Prest, stated:

It is heretical to suggest that the total control that a single individual is (and will always be) entitled to exercise over the affairs of his one man company is a feature resulting in the company's assets becoming assets to which he is entitled and therefore to which the company is not entitled. ${ }^{121}$

In relation to applying a legal principle based on trust law to justify the concealment principle, it may be plausible, in circumstances similar to Prest, to establish a resulting trust relationship between a company and its controlling shareholder. This approach will require, however, cogent evidence to displace the company's separate legal personality. ${ }^{122}$ Further, in appropriate circumstances, namely, where corporate property was acquired by a sham company following a breach of a fiduciary duty to a victim company by the controller of the sham company, it is not inconceivable that trust law may provide an alternative solution to piercing the corporate veil. For example, in such cases the sham company could be deemed liable to account as a constructive trustee for knowing receipt and the company's directing mind (usually the company's controlling shareholder) be found liable to account as a constructive trustee by way of dishonest assistance. ${ }^{123}$ The acceptance of such a scenario will depend, however, on whether the directing mind can, in effect, be 'double counted' to establish the culpability of the individual in control of the sham company. ${ }^{124}$

Contrary to the opinions expressed by Lord Sumption and Lord Neuberger, Baroness Hale $^{125}$ doubted the ability to classify previous piercing cases as either concealment or evasion cases. ${ }^{126}$ Instead, Baroness Hale believed that successful instances of piercing the corporate veil should be viewed more simply as examples of a much broader principle, namely that:

... the individuals who operate limited companies should not be allowed to take unconscionable advantage of the people with whom they do business. ${ }^{127}$

It is respectfully suggested, however, that while 'unconscionable advantage' is a recognisable characteristic in all successful piercing cases, it is in reality only a characteristic of the piercing cases as opposed to a universally applied piercing principle.

121 Prest (n 7) 445-56.

122 See e.g. Anglo German Breweries (in liq) v Chelsea Corporation Inc [2012] EWHC 1481 (Ch); [2012] 2 BCLC 632.

123 See the comments of Scott VC in Trustor AB v Smallbone (No 3) OT CA (Civ Div); 9 May 2000, para 61. Indeed, it is suggested that the ability to double count the directing mind in the case of Trustor affords a more appropriate explanation of the outcome of the case.

124 For an interesting but perhaps an ambitious use of the ability to double count the intention of the directing mind, see, C Witting, 'Intra-corporate Conspiracy: An Intriguing Prospect' (2013) 72(1) Cambridge Law Journal 178.

125 Lord Wilson expressed his agreement with the judgment of Baroness Hale.

126 Prest (n 7) 506. Without further and more detailed argument on the point, Lord Clarke also expressed reservations about the ability to classify the 'piercing cases' into concealment and evasion categories (508).

127 Ibid. 
Simply put, if the unconscionable advantage principle was apposite to properly explain and justify a piercing of the corporate veil, many more examples of veil-piercing by way of unconscionable advantage would already exist. The characteristics attached to unconscionable advantage ordinarily embrace a far wider range of misconduct which is more in line with the character of a 'pure' equitable fraud. In reality, equitable principles have not ordinarily been used in potential veil-piercing cases to a primary objective of establishing a fair and just view, or to sanction an enquiry into the reality of the situation, or to an overwhelming objective of delivering justice.

Of the remaining judgments, in Prest, and significant to the piercing issue, Lord Mance accepted the classification of cases into concealment and evasion cases, ${ }^{128}$ but, in unison with the views expressed by Lord Clarke, ${ }^{129}$ did not wish to foreclose all possible future situations in which a court would be justified in piercing the corporate veil. Both their Lordships accepted, however, that such situations were likely to be novel and very rare. Here, with some disappointment, Lord Clarke did not elaborate on the views which he had previously expressed in VTB Capital, ${ }^{130}$ namely his Lordship's doubt about the correctness of overturning the decision to pierce the corporate veil in Gramsci.

\section{Conclusion}

Following the opinions advanced by the Justices of the Supreme Court in both VTB Capital and Prest, it is most likely that in future an ability to pierce the corporate veil will be limited to a point of near extinction. In all probability, a piercing of the corporate veil will be invoked only as a last resort in accordance with the evasion principle and will be completely unnecessary where, in the preferred alternative of a majority of the Supreme Court, the circumstances of a case justify the application of the concealment principle. In the context of a one-man-type company, however, applying the concealment principle by invoking agency principles would, it is respectfully suggested, appear to run contrary to the reasoning applied in Salomon $v$ A Salomon \& Co Ltd.

To conclude, in its present form the evasion principle is comprised of a technical and arbitrary set of rules derived from a specific factual situation found in Gilford Motor Co v Horne. ${ }^{131}$ While the rarity of its application facilitates a protective climate of legal certainty in the promotion and acceptance of the incorporation process, as a cost, its inflexibility expedites fraud. Here, it is possible to describe the rigid interpretation of the Salomon principle and the inelasticity of the evasion principle as 'calamitous'. ${ }^{132}$ The evasion principle is, in truth, artificial and its acceptance limits the spirit of the House of Lords' judgment in Salomon, in which the House conveyed a more extensive acceptance of an ability to disturb a company's distinct legal status in circumstances where the incorporation process served an illegitimate and fraudulent end. It is submitted, therefore, that the correct and true piercing principle, which was advocated by a majority of the Supreme Court as the evasion principle, could and should in the future be expanded to embrace the fraudulent incorporation concept. While remaining subservient to the Salomon principle, the fraudulent incorporation concept would extend the current evasion principle to the just objective of remedying fraudulent conduct beyond the type of fraud which the evasion principle now seeks to preclude. To this end, it is submitted that this extension would be more in line with the true spirit of the Salomon judgment.

128 Prest (n 7) 507.

129 Ibid.

130 VTB Capital (n 95).

131 [1933] Ch 935.

132 See, O Kahn-Freund, ‘Some Reflections on Company Law Reform’ (1944) 7 Modern Law Review 54. 
